\title{
Edward Korczyński
}

\section{Ryszard W. Gryglewski}

Chair of History of Medicin, Jagiellonian University School of Medicine, Kraków, Poland

\begin{abstract}
This paper is focused on life and scientific achievement of Edward Korczyński, professor of internal diseases in Jagiellonian University, which is seen by many as a pioneer of modern clinic of internal disease in Poland. Korczyński's name is given just aside such great physicians as Joseph Dietl or Tytus Chałubiński. It is due to his works nitroglycerine was introduced into clinical practise, and it is him, who first in the world could diagnose infarct of the heart in a patient, which became classical and canonical in medicine.
\end{abstract}

Key words: internal disease, nitroglycerine, Jagiellonian University

Edward Korczyński should be seen as one of the most eminent Polish physicians of the $19^{\text {th }}$ century. Sometimes named "the last classical internist in Poland" - alongside with Joseph Dietl and Tytus Chałubiński - he was a founder and pioneer of a modern clinic of internal diseases. Born in Dobromil, he attended primary school in Nowy Targ and gymnasium in Kraków. Then he became a student of the Medical Faculty at the Jagiellonian University. Korczyński graduated in 1868 and soon afterwards started practicing as a physician in Dembica. In 1869 he was offered an appointment in the Internal Clinic at the Jagiellonian University as assistant of Professor Karol Gilewski, where he was very quickly recognized as an outstanding diagnostician and gifted organizer. In 1872, at the age of 28, Korczyński became ward head in St Lazarus' Hospital in Kraków, and two years later he was given the chair of the Internal Diseases Clinic at the Jagiellonian University, where he worked until his death.

Korczyński reorganized with energy and talent the hospital's work schedule. Through his efforts the Clinic obtained more beds, more assistants and a very modern ambulatory. From the very beginning he strived for founds to build new clinical buildings. It was not an easy task. At last, in 1898 the construction could be started, and it was planned that the buildings would be opened in 1900. The choice of that date was not a chance decision. The year 1900 was the five-hundredth anniversary of the foundation of the Jagiellonian University and the silver jubilee of Korczyński's work as head of the Clinic. It was the last year of the $19^{\text {th }}$ century as well. To celebrate their master Korczyński the students prepared a special edition of all his printed clinical papers. Because of delays and some problems with building materials the construction

Correspondence to:

dr n. hum. Ryszard W. Gryglewski, Katedra Historii Medycyny, Collegium Medicum Uniwersytetu Jagiellońskiego, ul. Kopernika 7, 31-034 Kraków, Poland, phone: +48-012-422-21-16, e-mail: wgryglew@cm-uj.krakow.pl

Received: May 16, 2007. Accepted in final form: May 22, 2007.

Conflict of interest: none declared.

Pol Arch Med Wewn. 2007; 117 (4): 196-198

Copyright by Medycyna Praktyczna, Kraków 2007 works were seriously delayed, so the opening ceremony had to be transferred to the year 1901 [1].

The second half of the $19^{\text {th }}$ century was a time of great changes in understanding and viewing the place of biological disciplines, including medicine of course, in the realm of sciences. Deep transformations which were then taking place in surgery, with the innovation of narcosis and antiseptic treatments, the birth of pathological anatomy and the real beginnings of physiology and biochemistry, had a great impact on understanding the sense and nature of medical theory and practice. When Korczyński entered the clinic for the first time, internal diseases were understood as the medicine of all illnesses which could be treated by non surgical methods. At the time of Korczyński's death there was already a wide specialization, with cardiology, gastrology and pulmonology as leading fields. The modernization was made in many aspects by Korczyński himself.

As concerns clinical works Korczyński paid special attention to the circulatory system. He was the very first in the world to make the correct diagnosis of a myocardial infarction in patients. A precise description should be seen as canonical for the clinical diagnosis [2]. He was again the first in Poland to use nitroglycerine in clinical therapy [3]. With his students he conducted wide pharmacological tests on this substance in clinical conditions.

Korczyński had a talent for choosing right people as his assistants. It was even a kind of intuition that led to making the very beginnings of Polish gastrological school. Walery Jaworski and Antoni Gluziński, two famous Polish gastrologists, were Korczyński’s students. In 1885, due to Gluziński and Jaworski's research, a proper level of gastric acid could be marked for the first time. Korczyński, Jaworski and Gluziński [ not taking into account casuistic papers by Reichman] connected gastric hyperacidity with chronic gastric ulcer disease and chronic duodenal ulcer disease. The research team pointed on relations between the level of gastric acid and morphological changes occurring in stomach mucosa, and showed the relation of hypochloraemia with a general condition of the organism. 
Korczyński is remembered as a severe and pedantic man, but he was admired by many for his high moral principles and readiness to help others. He took the chair of Internal Diseases in such a young age that his students were only a few years younger than him. Korczyński quickly became very popular among them. When he rejected the office of Protomedic of Galicia offered him by the government of Austria, his students were enthusiastic . It was seen as a patriotic gesture against the Austrian oppressor. In the year 1889 the Senate made him rector of the Jagiellonian Uniwersity. Again young students were enthusiastic, but what was more important, Korczyński’s nomination had a full acceptance of the Austrian authorities. Korczyński always declared himself to be a conservative, loyal to the Viennese government.

The end of the 1880s was a time of political fewer. The idea of revolution was again strong among young people, and in Galicia the socialist movement was steadily growing up, with the Polish Socialist Party, born in 1892, in the lead. Korczyński was against those movements and strongly condemned the idea of socialism. When the group of students gathered around the editorial staff of the academic journal Ognisko (Fire) openly declared the need for the struggle for Poland's independence on socialistic grounds, the Austrian authorities demanded a special investigation in this matter. The Senate of the Jagiellonian University set up a special committee to institute disciplinary proceedings. By its decision the whole group of students was relegated from the University. Korczyński, as the university's rector, put his signature on the relegation document, which was seen by the young men as an act of treason [4]. The Korczyński's apartment was thrown over with stones, some windows were broken, and the clay bust of Korczyński, only a few years earlier founded by students to memorize their beloved tutor, was then broken to pieces. In the group of students destroying the bust was Maximilian Rutkowski, in the future one of outstanding Polish surgeons and a professor of surgery at the Jagiellonian University [5]. The student demonstrations were so violent that police and even military forces were put into action. This situation had a devastating effect on Korczyński's psychical condition. He became even more withdrawn and distrustful, and started to isolate himself from friends and colleagues. Malicious and atrabilious, he was getting more and more whimsical. He was often seen perfectly dressed driving through the city in a black carriage drawn by two horses. Lofty and stiff, lacking any sense of humor, Korczyński was an easy target for often dirty jokes, which made him yet more ill disposed towards the human race. His cup of bitterness was filled to the brim when in 1902 Korczyński was accused of the unjustified dismissal of one of his assistants. And again there were protests, demonstrations and the police investigating the charges. Those events finally broke down Korczyński's soul. He gave away most of his occupations and retired from public life. The heart disease from which he had suffered for years, made a dangerously fast progress. Korczyń-

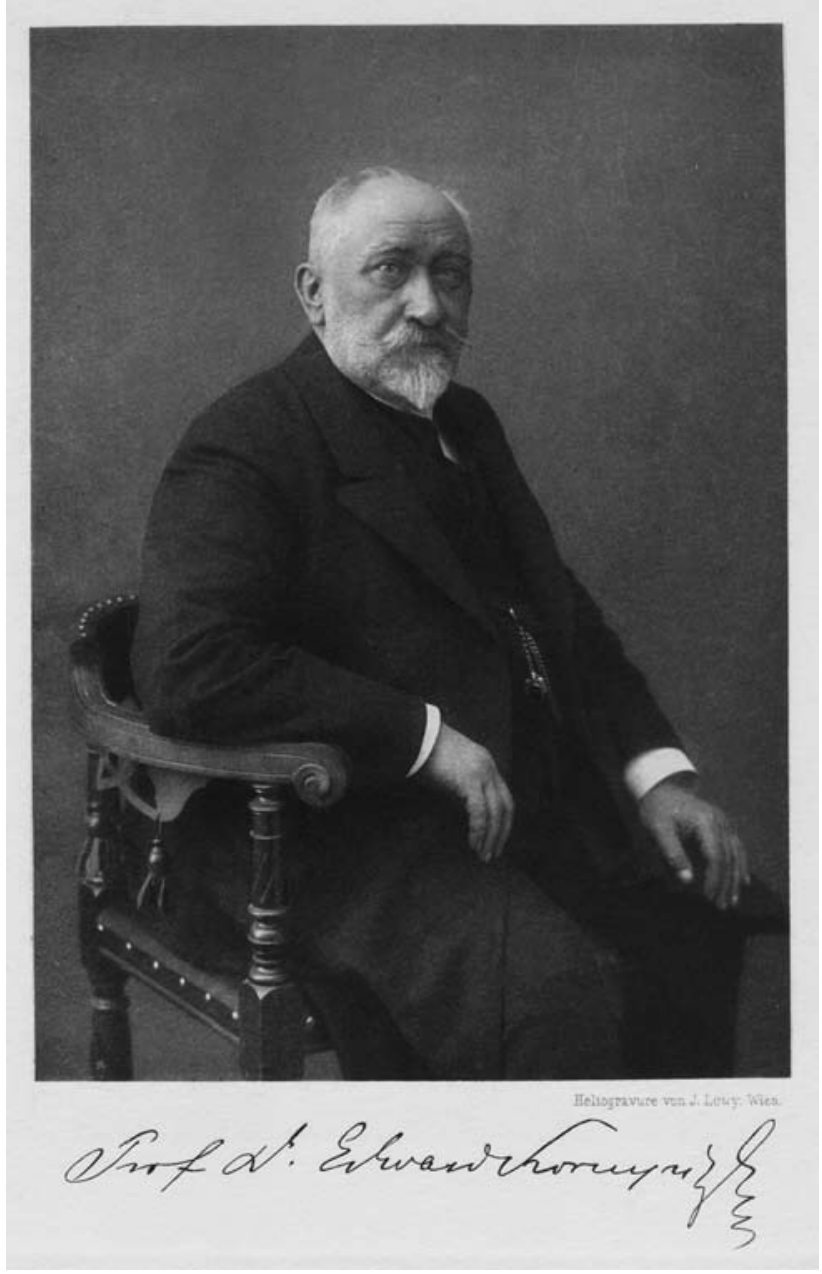

Fig. Edward Korczyński (1844-1905) (from collection of Chair of History of Medicin, Jagiellonian University School of Medicine, Kraków, Poland)

ski was aware of this but did not want any help, even from his students, like Jaworski and Gluziński who were always loyal to their tutor. He died at home on 23 September 1905.

\section{REFERENCES}

1. Gajda Z. 0 ulicy Kopernika w szczególności, o Wesołej w ogólności prawie wszystko. Kraków, UJ, 2005: 87-88.

2. Korczyński E. Zator tętnicy wieńcowej serca (Embolia arteriae coronariae cordis) za życia rozpoznany. Przegl Lek. 1887; 1: 20-21, 1887; 3: 41-43, 1887; 4: 57-59, 1887; 5: 75-76.

3. Korczyński E. Kilka stów o działaniu fizyologicznem i o zastosowaniu leczniczem nitrogliceryny (na podstawie doświadczeń wykonanych wspólnie z Michałem Janochą). Pamiętnik Towarzystwa Lekarskiego Warszawskiego 1881; 4: 609-628.

4. Aleksandrowicz J, Lisiewicz J. Edward Korczyński (1844-1905). In: Sześćsetlecie medycyny krakowskiej. T. 1. Kraków, Akademia Medica Cracoviensis, 1963: 162163.

5. Gajda Z. 0 wydziale lekarskim Uniwersytetu Jagiellońskiego. Kraków, UJ, 2005: 123. 